\title{
Unsaturated polyester composite reinforced with Caroá fiber (Neoglaziovia Variegate): water sorption and mechanical properties
}

\author{
Ana Flávia Camara Bezerra ${ }^{1}$, Wilma Sales Cavalcanti ${ }^{1}$ \\ Antônio Gilson Barbosa de Lima ${ }^{1}$, Maycon James de Souza ${ }^{1}$, \\ Tulio Rafael Nascimento Porto ${ }^{1}$
}

\author{
${ }^{1}$ Academic Unit of Mechanical Engineering, UFCG - PB, 58429-900, Campina Grande, PB, Brazil \\ e-mail: anaflavia.dema@yahoo.com.br \\ e-mail: wilmasalescavalcanti@gmail.com; antonio.gilson@ufcg.edu.br; mjames.souza@gmail.com; \\ trnporto@gmail.com
}

\begin{abstract}
Aiming to minimize the environmental pollution and reducing the production costs of the composite materials, the use of plant fibers improves their physical and mechanical properties. On the other hand, fibers have high water absorption, which may increase their volume and weaken the fiber/matrix interaction, affecting the mechanical features of the composites. Concerned with this problem, this research had the objective of making 3 and 10 millimeter-thick specimens, containing 23\% $(\mathrm{m} / \mathrm{m})$ of Caroa fibers and 73\% (m/m) of unsaturated polyester. Samples were withdrawn after 0, 2, 4, 7, 12 and 21 days of exposure at room temperature water (ASTM D570 - 98). Then, the test of tensile (ASTM D 3039), flexural (ASTM D 790-03) and impact (ASTM D 256) was realized and the mechanical properties were analyzed. The samples subjected to humidity had their fibers degraded and presented loss of mechanical properties, more significant in composite with $3 \mathrm{~mm}$. For example, the reduction of the strengths tensile, after 21 days of test were $80 \%$ for composites with $3 \mathrm{~mm}$ and $60 \%$ for composites with $10 \mathrm{~mm}$. Studies like this are important for long-term applications of such composites in humid environments.
\end{abstract}

Keywords: Caroa fiber, Polyester, Sorption of water, Mechanical properties.

\section{INTRODUCTION}

Reinforced composites with vegetable fibers have good mechanical properties, low cost and low density compared to synthetic fibers [1]. However, there is one problem associated with the use of vegetable fibers with respect to exposure to humid environments: the hydrophilic nature of the vegetable fibers promotes increases in the internal stresses and weakens the composite interaction fiber / matrix; this phenomenon affects the properties of composites, especially the mechanical properties. Studies using natural fibers in polymer composites show the mechanical behavior and the humidity sorption of composites as in [2]. It was conducted a comparative study of flexure mechanical properties in reinforced composites with glass fibers, Curaua fiber (Ananas erectifolius) and composite hybrid glass / curaua. It was also performed tests of water absorption for all three laminates and analyzed the influence of absorption on the mechanical properties of the composites. The authors noted that hybridization was efficient in decreasing the water absorption of the composite curaua. The hybrid composite developed proved to be a promising substitute for glass fiber laminates, even in applications of contact with water, such as tanks and pipes.

Brazil is a country that stands out in the production of some fibers like sisal (Agave sisilana) and Caroa (Variegata Neoglaziovia). Found in the Caatinga, the plant Caroa presents economic potential centered on the leaves, which are made of high-strength fibers and are used in making twines, fishing lines, fabric, craft and decorative pieces. Beyond to vegetable fibers, organic resins are used in making composite materials. Sustainable resins uses renewable sources (plant) and recycled thermoplastics (postconsumer) in its manufacture and has orthophthalic base, terephthalic, dicyclopentadiene (DCPD) and isophthalic [3].

From this perspective, this paper analyzes the sorption and the mechanical behavior in traction, three point bending and impact for composites made of Caroa / unsaturated polyester when exposed to 
water bath. This level of information is important for the most accurate knowledge of this kind of composite, both academy and industry in this field, are interested in the uses of these materials for confection of new products.

\section{MATERIALS AND METHODS}

The fibers Caroa were provided by the industries FibraNatu in Olivedos, PB. The matrix was a pre-accelerated with unsaturated ortophtalic polyester resin, coded BP 290, provided by Elekeiroz in São Paulo, SP. This polyester resin is a new product from Elekeiroz, which is partially obtained from renewable sources and a recycled resin. The curing agent employed was 1\% Methyl ethyl ketone peroxide (PMEK).

To manufacture the Caroa composite, the fibers were cut manually with approximately two centimeters in length, and was in incubator for 20 minutes at $75^{\circ} \mathrm{C}$. The fiber layers were weighed with five grams in analytical balance with accuracy of $\pm 0.1 \mathrm{mg}$ and were shaped as rectangular metallic mold. In order to obtain the specimens made of the same percentage of fibers with different thicknesses ( 3 and $10 \mathrm{~mm})$, it was used two molds with the same length $(200 \mathrm{~mm})$ and width $(150 \mathrm{~mm})$ but different thicknesses. In each mold, it was arranged five webs each weighing 5 grams. Interleaved the blanket was poured into the mixture of resin and 1\% catalyst - methyl ethyl ketone peroxide - MEKP. To better accommodation of the fibers in the mold, the assembly was disposed in a hydraulic press under 10 tons of cargo at room temperature for 1 hour. Then, the press was preheated for 20 minutes to reach a temperature of $75^{\circ} \mathrm{C}$ and to place the complete curing of the resin, the mold was kept in the press for 2 hours. To determine the composite fiber content, Caroa blankets, before being placed in the mold, were weighed as also their respective composites. With this weights, the fiber mass content was determined by following Equation 1:

$$
\mathrm{T}_{\mathrm{f}}=\mathrm{P}_{\mathrm{m}} / \mathrm{P}_{\mathrm{i}} * 100
$$

Where, $\mathrm{T}_{\mathrm{f}}=$ fiber content $(\%) ; \mathrm{P}_{\mathrm{m}}=$ weight of the blanket $(\mathrm{g}) ; \mathrm{P}_{\mathrm{l}}=$ weight of the laminate.

In order to assess the percentage of water sorbed over time and hydromechanical behavior - via tensile strength, bending in three points and izod impact - of composites with 3 and $10 \mathrm{~mm}$ thickness, the samples were placed in a water bath and removed at pre-established time (0, 2, 4, 7, 12 and 21 days) to achieve the hydromechanical tests. For each mechanical test, it was tested five specimens.

Many authors have different opinions regarding the mechanisms and kinetics of water absorption, as [4], who consider that the water absorption in composite materials can be characterized by the diffusion of Fick, following Equation 2:

$$
\mathrm{F}=-\mathrm{D}_{\text {dif }} \nabla_{\mathrm{m}}
$$

Where, $F=$ fluid flow; $\underline{D}_{\text {dif }}=$ diffusion coefficient e $\nabla_{m}=$ concentration gradient.

Sorption of water test: The samples used in the sorption of water test were subjected to tensile (ASTM D 3039), flexural (ASTM D 790) and impact (ASTM D 256). The edges of the samples were sealed by a coating resin to prevent direct contact between water and fibers, prevent capillary sorption. Prior to sorption testing, the specimens were dried in an incubater at $105^{\circ} \mathrm{C}$ for 24 hours and immediately after, they were weighed and measured, and then immersed in distilled water at water bath. At predetermined times, the samples were removed from the water, dried with absorption paper and tested their mechanical properties flexural, tensile and impact efforts. The percentage of water sorption in the composite was calculated from Equation 3:

$$
\Delta \mathrm{M}=\left(\mathrm{M}_{\mathrm{f}}-\mathrm{M}_{\mathrm{i}}\right) / \mathrm{M}_{\mathrm{i}} * 100
$$

Where: $\Delta M=$ water sorption (\%); $M_{f}=$ weights of the samples after immersion in water; $M_{i}=$ weights of the samples before immersion in water.

Tensile test: Following the standard of a American Standards of Testing Materials ASTM D 3039 
standard for tensile testing, the samples were cut as rectangular. In Loyd Instruments LR 10K machine, the specimens were moved by tensile to fracture with a displacement rate of $1 \mathrm{~mm} / \mathrm{min}$.

Flexural strength at three points test: Following the ASTM D 790, for flexural test at three points, the samples were cut as rectangular bars dimensions 3 and $10 \mathrm{~mm}$ of thickness. For the three point bending test, the ends of the test specimens were supported on fixed static supports in the testing machine brand model Emic DL 10000 - 100KN. At its center, through mobile support, a force was applied to break the specimen with displacement rate $5 \mathrm{~mm} / \mathrm{min}$ and ware maintained $40 \mathrm{~mm}$ between the supports.

Izod impact test: The impact test (ASTM D 256) was carried out at water bath in $5.5 \mathrm{~J}$ CEAST Resil equipment, operating with an impactor of $2.75 \mathrm{~J}$ in specimens. The energy of impact, abruptly absorbed by a pendulum impacts not notched, was registered and calculated by Equation 4:

$$
\mathrm{RI}=\left(\mathrm{E}-\mathrm{E}_{1}\right) / \mathrm{e}
$$

Where : RI = Impact resistance $(\mathrm{J}) ; \mathrm{E}=$ specimen energy $(\mathrm{J})$; E1 = air energy $(\mathrm{J})$; e $=$ thickness of the test sample $(\mathrm{m})$.

\section{RESULTS AND DISCUSSION}

The Fig. 1 illustrates the effect of the water absorption by the Caroa / unsaturated polyester composite with 3 to $10 \mathrm{~mm}$ thickness.

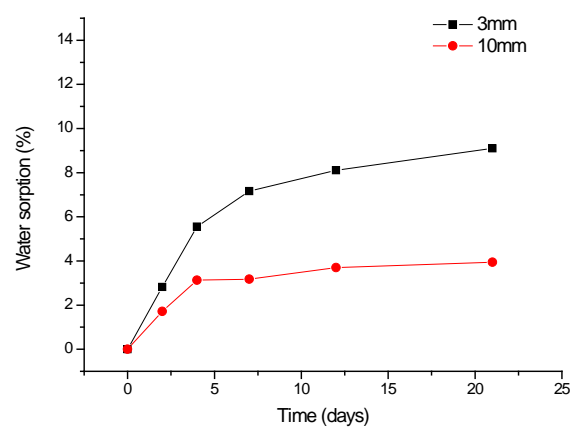

Figure 1: Water-absorbing effect depending on the immersion time in water the composite 3 and $10 \mathrm{~mm}$.

Analyzing the results of Fig. 1, it is observed that the water sorption rate occurs more significantly at the beginning of the test. After this period, the values tend to stabilize reaching values close to constant, corroborating the results reported by [5]. According to [6], the lignocellulosic materials have a tendency to absorb moisture, as these are mainly cellulose, lignin and hemicellulose. Hemicellulose are considered the main responsible for the absorption of water, although non-crystalline cellulose and lignin also play an important role in this process. The cell wall of lignocellulosic fiber swells until the water saturation be achieved. Then, the water starts to occupy the free spaces between the fiber bundles and changes their dimensions [7].

It is observed that composites with $3 \mathrm{~mm}$ of thickness exhibited higher sorption rate than composites with $10 \mathrm{~mm}$. It happens because of the smaller area of the composite. The larger area / volume ratio, promotes greater rate of water sorption, a fact observed by [8], which analyzed the absorption of water content in prepared macambira / unsaturated polyester composites.

The graph of Fig. 2 (a) shows the effect of water absorption on the tensile strength for the $3 \mathrm{~mm}$ and $10 \mathrm{~mm}$ composite and the graph of Fig. 2(b) the effect of water absorption on the mechanical properties of modulus of elasticity in traction, as a function of immersion time in water for the $3 \mathrm{~mm}$ and 10 mm composite. 

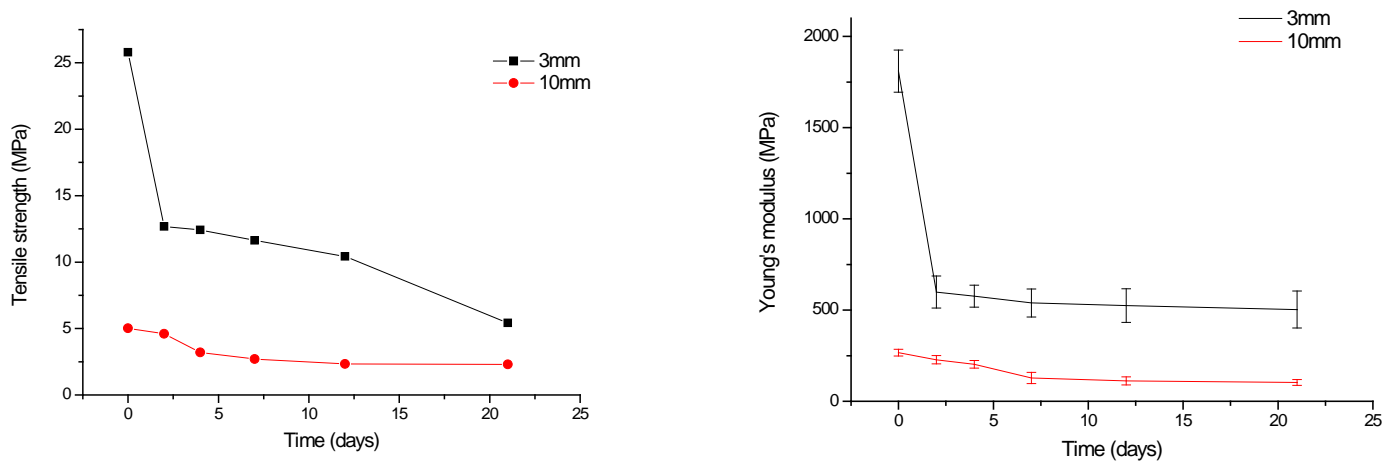

Figure 2: a) Water-absorbing effect the tensile strength as a function of immersion time in water in the $3 \mathrm{~mm}$ and 10 $\mathrm{mm}$ composite b) Water-absorbing effect on the modulus of elasticity in traction as a function of immersion time in water in the $3 \mathrm{~mm}$ and $10 \mathrm{~mm}$ composite

Through the graph of Fig. 2 (a), it can be seen that the tensile strength values are higher in the initial time of the test. The maximum tensile strength of the test specimens of $3 \mathrm{~mm}$ thickness is $25.79 \pm$ $2,29 \mathrm{MPa}$ and the maximum resistance of the composite with $10 \mathrm{~mm}$ thickness is $5.02 \pm 0,26 \mathrm{MPa}$. The initial result of tensile strength of composites with $3 \mathrm{~mm}$ thickness was close to that presented by [9], that studied composites made from polyester and sisal fiber with $2 \mathrm{~mm}$ thickness and $30 \%$ of fibers, and by [10], which analyzed fiber composites made of curaua and glass, with $2 \mathrm{~mm}$ of thickness and with approximately $20 \%$ of volume fraction.

Comparing the initial tensile resistance of the Caroa / polyester composite with 3 and $10 \mathrm{~mm}$ thicknes is possible to observe that the thinner composite have the tensile strength about $80 \%$ larger compared to the thickest; the larger area of composite, promotes the lower strength tensile during the test. Analogous behavior has been reported by [11], the authors have ratified that tensile strength behavior is better in the sample that absorb less umidity. According to [12], these reductions are related to water diffusion 'inflates' the fibers prompting microcracks due to the trapped of water.

In related systems, as written by $[9,13]$, we observed a decrease in tensile strength for longer times of thermal exposure. According to [14], the thermal degradation of the system leads to reduction of the reinforcing capacity of the fiber and the adhesion in the matrix, becoming a filler material, with the aggravating of being hygroscopic and putrescible. This phenomenon can be aggravated by variation umidity on the matrix.

Through the Fig.2 (b) graph, it can be observed that the higher values in the modulus of elasticity in traction are found in the initial moments of the water absorption test, $1810 \pm 115 \mathrm{MPa}$ for $3 \mathrm{~mm}$ thickness composites and 266.64 $\pm 19 \mathrm{MPa}$ for $10 \mathrm{~mm}$ composites. The initial value of the modulus for the composite with $3 \mathrm{~mm}$ was similar to that found by $[15,16]$, which analyzed composites made with pineapple and sisal fibers, respective.

It is possible to observe that the thicker composite has a lower modulus of elasticity in traction in compared to the thinner composite. As composites have the same fibers content, the thicker composite has a greater free movement of polymer chains, which results in lower modulus of elasticity. According to [17], the reduction in mobility of the chains into the matrix occurs due to the presence of fibers, increases the composite elastic modulus of the. On the tensile strength test, the values of the elastic modulus in traction were initially higher, followed by considerable fall.

The Fig. 3 (a) illustrates the results of water absorption on the flexural strength Caroa / unsaturated polyester with 3 and $10 \mathrm{~mm}$ composite depending on the immersion time in water and the graphs of Fig. 3 (b) shows the results of water absorption on the impact resistance of the Caroa / unsaturated polyester 
with 3 and $10 \mathrm{~mm}$ composite depending on the immersion time in water.
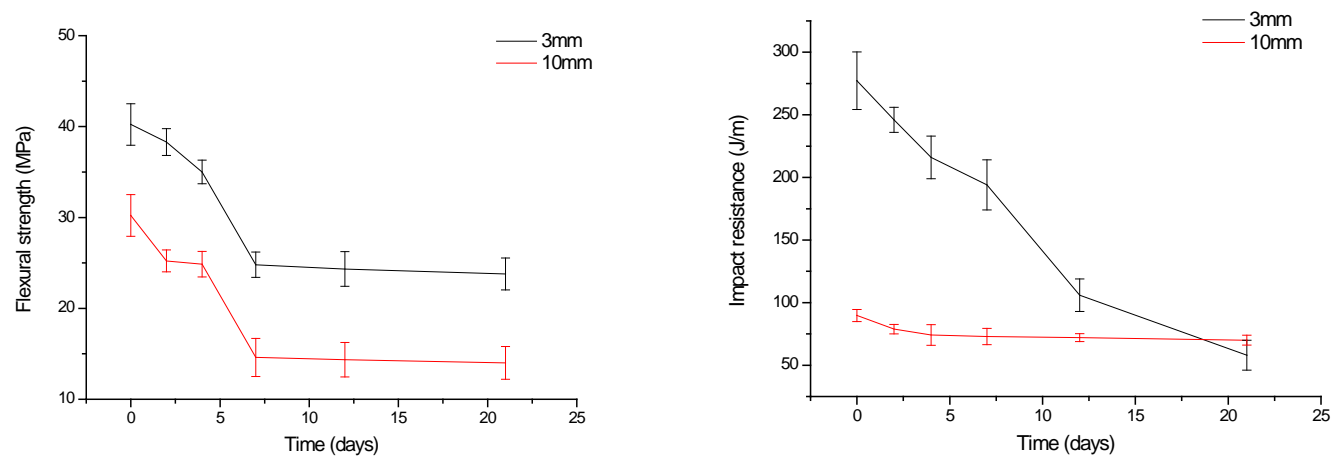

Figure 3: a) Effect of water absorption on the mechanical properties of impact resistance as a function of immersion time in water in the $3 \mathrm{~mm}$ and $10 \mathrm{~mm}$ composite b) Effect of absorption of water on flexural strength as a function of immersion time in water for the $3 \mathrm{~mm}$ and $10 \mathrm{~mm}$ composite.

Analyzing the mechanical properties for flexure, illustrated on Fig. 3 (a), it is observed that the initial values of flexural resistance are higher in the early stages of the test. Initially, the $3 \mathrm{~mm}$ thickness composite has 40MPa flexural strength and the composite with $10 \mathrm{~mm}$ thickness $30 \mathrm{MPa}$. These figures were similar to the composites presented by [18], which analyzed composites made from sugar cane bagasse with $3 \mathrm{~mm}$ thickness. According to [19], the study of the flexural strength of composites allows to evaluate the material behavior in flexural resist to forces applied perpendicularly longitudinal axis.

During the test, the flexural resistance decreased. The decrease of mechanical properties of composites values is related to the decrease of interfacial adhesion at the fiber matrix caused by composite water absorption. The water penetrates into the composite and as a result, the links between the resin and the fibers break, which explains the decrease in mechanical properties.

The graph of Fig. 3 (b) illustrates that the highest impact strength values are found in the initial moments of the water absorption test: $277.21 \pm 23 \mathrm{~J} / \mathrm{m}$ for composites with $3 \mathrm{~mm}$ thickness and $89.7 \pm 4$ $9 \mathrm{~J} / \mathrm{m}$ for composites $10 \mathrm{~mm}$ thickness. For $3 \mathrm{~mm}$ composite, the initial impact resistance value was similar to those found in [20], which confectioned with $3 \mathrm{~mm}$ thickness and $23 \%$ of coconut fibers and was similar to the composite developed by [21], which analyzed the impact resistance of a composite with $4 \mathrm{~mm}$ thicknes and with 32\% of glass fiber and curaua.

According to the Figure 3, it is noted that composites have a in impact resistance reduction with time of water sorption; For example, the composite that initially presented $277 \mathrm{~J} / \mathrm{m}$ impact strength, and after 21 days of test $78 \mathrm{~J} / \mathrm{m}$. This reduction can be interpreted as result of degradation of lignocellulosic fibers does to a prolonged exposure in water.

The impact resistance is a complex property, since it is associated with the toughness of the material, ie, it depends on its strength and ductility, which made [16] affirm that impact tests on reinforced panels with vegetable fibers are inadequate as an indicator of degradation due to the high variability of the results.

\section{CONCLUSIONS}

In this research, an experimental study about water absorption and its effect in mechanical properties of an unsaturated polymer composites reinforced with vegetable fiber (Caroa plant) at different temperatures. From the results, we can conclude that the water sorption kinetics in the Caroa / unsaturated polyester composite is influenced by temperature and area / volume ratio.

The water sorption rate occurs more significantly in early testing. After this period, the values tend to stabilize reaching values close to constant. Composites with $3 \mathrm{~mm}$ thickness exhibit higher sorption 
rate than composites $10 \mathrm{~mm}$ thickness. The composites show a reduction in tensile strength, flexural and impact over time of water sorption. Composite with $10 \mathrm{~mm}$ thickness has lower tensile, flexural and impact compared to $3 \mathrm{~mm}$ thickness composite. The higher values in the modulus of elasticity in traction are found in the initial moments of the water absorption test and the thicker composite had lower modulus of elasticity in traction in relation to the $3 \mathrm{~mm}$ composite.

\section{BIBLIOGRAPHY}

[1] CARVAlHO, L. H., LIMA, A. G. B., BEZERRA, A. F. C., ET AL., "Water Sorption of Vegetable Fiber Reinforced Polymer Composites”, Defect \& Diffusion Forum, v.369, pp. 17-23, 2016.

[2] SILVA, R.V., AQUINO, E.M.F.., RODRIGUES, L.P.S, et al.,“Development of a hybrid composite with synthetic and natural fibers”, Revista Matéria, v.13, n.1, pp. 154 - 161, 2008.

[3] SILVA, C.J., ANDRADE, T.H.F., SILVA, E.G., et al., "Water Absorption in Composites Reinforced with Caroá Fiber Fabrics: Modeling and Simulation via ANSYS CFX®”, Defect and Diffusion Forum, 353, pp. 84-89, 2014.

[4] ZHOU, J., LUCAS, J.P. "Higrothermal effects of epoxy resin. part i: the nature of water in epoxy", Polymer, v.40, n.20, pp. 5505-5512, 1999.

[5] NÓBREGA, M., CARVALHO, L., FONSECA, V. "Tensile and impact properties of macambira and Caroa fiber reinforced unsaturated polyester composites”, International Conference on Science e Technology for Sustainable Development, New Delhi, pp. 1-14, 2006.

[6] PAUlA, G.P., RODRÍGUEZ, R. J. S., RANGEL DUARTE, L. P., et al, "Formulation and characterization of polypropylene composites alkali treated bagasse fiber", Materials Science Forum, v.775, pp. 319-324, 2014.

[7] DAS, S., SAHA, A.K., CHOUDHURY, P.H., et al., "Effect of steam pretreatment of jute fiber on dimensional stability of jute composite”, Journal of Applied Polymer Science, v.76, n.11, pp. 1652-1661, 2000.

[8] CRUZ, V. C., NÓBREGA, M.M., CAVALCANTI, W.S., et al., "Water absorption in macambira / unsaturated polyester composites: an experimental study”, In: VI Congresso Nacional de Engenharia Mecânica - CONEM 2010, Brazil, pp. 1-5, 2010.

[9] JOSEPH, K., MEDEIROS, S.E., CARVALHO, L.H. “Tensile properties of unsaturated Polyester composites reinforced by short sisal fibers”, Polímeros: Ciência e Tecnologia, v.9, n.4, pp.136-141, 1999.

[10] SILVA, H.S., JUNQUEIRA, D., MORAES, A.G., et al.,"Development of thermoset polymer composites with curaua fibers”, In: $18^{\circ}$ Congresso Brasileiro de Engenharia e Ciência dos Materiais - 18 CBECiMat 2008, Brazil, pp. 4558-4569, 2008.

[11] RAYMUNDO, E.A., RIBEIRO, R.B., CARVALHO, E.F., et al., "Analysis of water absorpition in polymeric composites reinforced with natural reinforced with natural fibres”, Cadernos UniFOA, Special edition, pp.23-28, 2012.

[12] DARROS, A.B., PAIVA, J.M. Thermal and mechanical properties of composite matrices of epoxy resin reinforced with random webs of vegetable fiber, In: $11^{\circ}$ Congresso Brasileiro de Polímeros - $11^{\circ}$ CBPol, Brazil, 2011.

[13] ALSINA, O.L.S., CARVALHO, L.H.D., RAMOS FILHO, G.R. "Thermal properties of hybrid lignocellulosic fabric-reinforced polyester matrix composites”, Polymer Testing, v.24, n.1, pp. 81-85, 2005.

[14] AGOPYAN, V., JOHN, V.M. "Durability evoluantion of vegetable dibre reinforced materials", Building Research \& Information, v. 20, pp. 233-235, 1992.

[15] LIU, W., MISRA, M., ASKELAND, P., et al., "Green” composites from soy based plastic and pineapple leaf fiber: fabrication and properties evaluation”, Polymer, v.46, n.8, pp. 2710-2721, 2005.

[16] Li, Y., Mai, Y., Ye, L. "Sisal fibre and its composites: a review of recent developments", Composites Science and technology, v. 60, n.11, pp. 2037-2055, 2000.

[17] XUE, Y., VEAZIE, D.R., GLINSEY, C., et al., "Environmental effects on the mechanical and thermomechanical properties of aspen fiber polypropylene composites”, Composites Part B: Engineering, v. 38, pp. 152-158, 2007. 
[18] SANCHEZ, E.M., CAVANI, C.S., CLAUDINETE, V., et al. "Unsaturated polyester resin composite with sugar cane bagasse: influence of treatment on the fibers properties”, Polímeros, v.20, n.3, pp. 194200, 2010.

[19] OLIVEIRA, A.K.F., D’ALMEIDA, J.R.M. "Description of the mechanical behavior of different thermoset composites reinforced with Manicaria saccifera fibers”, Journal of Composite Materials, v.48, n.10, pp. 1189- 1196, 2013

[20] BEZERRA, A.F.C., CARVALHO, L.H., SANTANA, L.N.“Unsaturated polyester/Caroa fiber composites”, In: 1 st Brazilian conference on composite materials - BCCM1, Brazil, pp. 1-6, 2012.

[21] ANGRIZANI, C., AMICO, S. "Influence of thickness on the mechanical properties of hybrid interlaminate of curaua/glass/polyester composites”, Polímeros, v.24, n.2, pp. 184-189, 2014. 